\title{
Transatlantica
}

Revue d'études américaines. American Studies Journal

$2 \mid 2011$

Sport et société / Animals and the American

Imagination

\section{Race and Redemption in the American Heartland}

With an Introduction by Françoise Palleau-Papin

Rilla Askew

\section{(2) OpenEdition}

\section{Journals}

Édition électronique

URL : https://journals.openedition.org/transatlantica/5598

DOI : $10.4000 /$ transatlantica. 5598

ISSN : $1765-2766$

Éditeur

Association française d'Etudes Américaines (AFEA)

Référence électronique

Rilla Askew, «Race and Redemption in the American Heartland », Transatlantica [En ligne], 2 | 2011,

mis en ligne le 19 juin 2012, consulté le 06 février 2023. URL : http://journals.openedition.org/ transatlantica/5598; DOI : https://doi.org/10.4000/transatlantica.5598

Ce document a été généré automatiquement le 6 février 2023

Creative Commons - Attribution - Pas d'Utilisation Commerciale - Pas de Modification 4.0 International - CC BY-NC-ND 4.0

https://creativecommons.org/licenses/by-nc-nd/4.0/ 


\title{
Race and Redemption in the American Heartland
}

\author{
With an Introduction by Françoise Palleau-Papin
}

\author{
Rilla Askew
}

\section{Introduction}

\section{"Rilla Askew, a voice on the stage of fiction" Françoise Palleau-Papin}

1 Rilla Askew is, to use a catch phrase, an acclaimed novelist. Beside the acknowledgements one may find on the web, an aside to her work says something about the way she writes. Before she turned to fiction, she studied drama in college, first at Northeastern State College in Tahlequah, Oklahoma. She went on to finish her undergraduate degree with a B.F.A. in Theater Performance from the University of Tulsa in 1980. She moved from Oklahoma to New York later that year to pursue an acting career. She studied acting with Herbert Berghoff at HB Studio in New York and later with Curt Dempster at Ensemble Studio Theater. Within a couple of years she also started writing: plays at first, and then fiction. She went on to graduate school at Brooklyn College to study writing and received an M.F.A. in Creative Writing in 1989.

2 Askew brought her acting acumen to fiction. Her work displays a mastery of rhythm and an ear for the sounds of language, not just in the dialogue passages, but everywhere in her prose. She renders the speech mannerisms of rural Oklahoma characters with a great taste for the creative possibilities of the fast disappearing idiom of common folks that goes back to Frontier days and the Bible. She does not record as much as she selects and brings out the poetry of folk language, not in any folkloric or nostalgic stance, but to explore the creative linguistic expression of a vision. In the novel The Mercy Seat, for example, a character rebukes herself and shies away from her own poetic phrasing, when she translates her first evocative sentence to a more downto-earth, abrupt correction: "Might've been four o'clock or so, because it was already starting to frown up and get dark. What I mean, evenings was short." (The Mercy Seat, 
281). The rebuke is the character's, not the author's, who orchestrates the silences and the unvoiced aspirations of the stunted characters. In that novel, there is an intensity of vision that takes one to the eye of the storm, and Rilla Askew's style manages to capture the hypnotic quality of the family drama that becomes the drama of an entire community. In the midst of disaster, her sentences expand the moment and resonate the stasis of the characters, providing an intense reading experience, yet not devoid of humor. Fellow writer Patricia Eakins has underlined Askew's filiation with other American writers of the epic tradition:

"Sometimes terrifying, sometimes lyric, sometimes funny, always engaging, her fiction like Faulkner's explores the related tragedies of family and history. As in the work of Cormac McCarthy, Askew shows how an unforgiving landscape resonates in human fate."

In Harpsong, her 2007 novel set in Oklahoma during the Depression, she inserts poems in prose between chapters, providing a pause in the narrative, an echoing chamber and a commentary on the action akin to a choric poem in a play. The novel changes narrative viewpoints and voices to resonate the mystery of the characters' motivations, which, to a large extent, remain a secret to themselves and to others. In her 2001 novel Fire in Beulah, Rilla Askew explores the murky and hysterical psyche of a crowd during the race riots that took place in Oklahoma in the 1920s. In her 1992 short stories collection Strange Business, she pictures the hushed lives of small town characters that add up to something akin to what Eudora Welty crafted in her collection The Golden Apples.

The list of her public awards is impressive. She received a 2009 Academy Award in Literature from the American Academy of Arts and Letters. Her essays and short fiction have appeared in a variety of journals, and her story "The Killing Blanket" was selected for Prize Stories 1993: The O. Henry Awards. Askew's first novel, The Mercy Seat, was nominated for the PEN/Faulkner Award, the Dublin IMPAC Prize, was a Boston Globe Notable Book, and received the Oklahoma Book Award and the Western Heritage Award in 1998. Fire in Beulah, her novel about the Tulsa Race Riot, received the American Book Award and the Myers Book Award from the Gustavus Myers Center for the Study of Bigotry and Human Rights. She was a 2004 fellow at Civiella Ranieri in Umbertide, Italy, and in 2008 her novel Harpsong received the Oklahoma Book Award, the Western Heritage Award, the WILLA Award from Women Writing the West, and the Violet Crown Award from the Writers League of Texas. The WILLA Award could be understood as the emblem of her achievement, as Rilla Askew may be considered an heir to Willa Cather, on her own premises and in her own time. Askew received the 2011 Arrell Gibson Lifetime Achievement Award from the Oklahoma Center for the Book.

Rilla Askew also devotes time and energy to an endeavor she has been committed to since her husband, actor and director Paul Austin, founded The Liberty Free Theater. In the town of Liberty, in the southern Catskills of New York State, far from the bustle of New York City and further off than any off-off Broadway show there may be, she has adapted some of her short stories for the stage, such as "Breakfast" in 2010. In 2011, she played the part of Eunice in the play "Strange Business," adapted from her eponymous story, first published in her 1992 collection Strange Business. She also wrote an original play that Paul Austin produced at The Liberty Free Theater in 2009, "By the Time We Got to Woodstock." 
Rilla Askew currently serves as Artist in Residence in the MFA Creative Program at the University of Central Oklahoma. She divides her time between the Catskills and Oklahoma. Her new novel, Kind of Kin, will be published by Ecco Press in 2013.

\section{"Race and Redemption in the American Heartland" Rilla Askew}

7 My fiction is set in my home state of Oklahoma-a meat-cleaver-shaped entity centered in the underbelly of the United States-during periods of powerful social upheaval and change: the settling of the American Frontier in the late 1800's, the oil boom and race riots of the 1920's, the Dust Bowl era of the 1930's. I've been called a historical novelist, but I don't think of my work that way. The history I write about exists in living memory, in the memories of my parents, who came of age during the Great Depression, and in my own memory, growing up, as I did, listening to stories told by my grandparents and great-grandparents. Nor do I consider myself a regional novelist. "America" is my subject. Oklahoma is the landscape where the story unfolds.

My great-grandparents migrated here in covered wagons in the late 1800's when Oklahoma was still Indian Territory. In 1907, at the stroke of a pen, Indian Territory became the $46^{\text {th }}$ state. And so Oklahoma is a young state, barely one hundred years old. Our brief, violent history is a microcosm of much that has taken place on the North American continent over the past five hundred years, but turned inside out, intensified, distilled. It's a tale of migration and restless movement, the conjunction of America's three founding races, Black, White, and Indian, a story of faith-not just religious faith, though that is surely part of the narrative-but also faith in the land and its people, and faith in the future, no matter how dark the present may seem.

People in Oklahoma have a way of standing with their hearts longing backwards and their eyes looking front, a simultaneous nostalgia for what is lost joined with a forward-looking optimism, that seems to me quintessentially American. The elemental sorrow and hope and homesickness of leaving one's homeland-emigration-and coming to a new land-immigration-are the very substance of the American story, inextricably entwined with the religious faith that is also a part of our substance.

The first Anglo settlers migrated to the New World to escape religious persecution, to establish societies where they could worship as they chose. Religion is still very much a part of the American character. It suffuses our politics, our culture, our literature. Whether you're reading William Faulkner or James Baldwin or Cormac McCarthy, you'll hear the rhythms and syntax of the King James Version of the Christian Bible.

11 Early on in our history, these Europeans-these white people-began to move from east to west across the face of the continent, 'conquering' the land, putting it under man's dominion, as their religion taught them was the proper God-ordained order. And so the story not only of emigration and immigration but also of migration-that great westward trek-is part of the story. The enslavement of African people, brought in slave ships to the New World in order to break the land and reap its economic benefits, this, too, is part of our story. Race and religion, immigration and migration, our love for the land and how we use and abuse its resources-these elements dominate America's story. They dominate Oklahoma's story. Always as a novelist I am looking to 
explore, explicate, demythologize America's Master Narrative, how that narrative has manifested in my own small, turmoil-filled state.

The name Oklahoma is derived from two Choctaw words: okla, meaning people, and humma, meaning red. The Choctaws were among the great settled tribes known to whites as the Five Civilized Tribes-the Choctaw, Cherokee, Seminole, Creek, and Chickasaw Nations-who, in the early 1800's, were forced from their homelands in the American South and marched west to the land that was to be called Indian Territory. This land was supposed to be theirs "as long as the grass should grow and the waters run." Some tribes lost as much as a quarter of their population to disease and starvation on those forced marches, which the U.S. government termed the Indian Removals but which became known among Indian people as the Trail of Tears. Today more Indian tribes survive and thrive in Oklahoma than anywhere on the continent, but with the bitter irony that in Oklahoma they don't live on "reservations" because in the Land of the Red People, Indians have lost most of their land. A few decades later, white settlers, hungry for land, lined up at the borders and, at the sound of a noontime gun-shot, raced forward on foot or on horseback or in wagons, rushing madly to stake their claims, so that new homesteads and entire towns sprang up on the prairie overnight.

13 In my novel The Mercy Seat, a white family leaves their Kentucky home abruptly in 1887, traveling west in a covered wagon with all their belongings and dogs and children, knowing -at least some of them-that they will never return home again. The seeds of the tale came to me through my own family's story, told to me by my elders: how my great-great grandfather and his brother fled Kentucky in the middle of the night because they had broken the laws there. They took their families and headed west to Indian Territory, where, as white people, they had no legal right to own land. That book begins:

14 "There are voices in the earth here, telling truth in old stories. Go down in the hidden places by the waters, listen: you will hear them, buried in the sand and clay. Walk west in the tall-grass prairie; you will hear whispering in the bluestem. Stand here, on the ragged rim of a mountain in the southeastern corner; you can hear the sound rising on the south wind, sifting in the dust through the crowns of the cedars: stories told in old voices, in the pulse of blood-memory; sung in the hot earth above the ceaseless thrum of locusts and night-birds singing, beneath the faint rattle of gourd shells. One story they tell is about longing, for this is a place of homesickness. The land has become home now, and so the very core of this land is sorrow. You can hear it longing for the old dream of itself. Like this continent. This country. Oklahoma. The very sound of it is home.

15 "When the Choctaw people knew white soldiers were coming to force them from their homes to this unknown land in the west, the people walked for the last time in their forests and touched their hands to the trees, the rocks, and healing plants, to say goodbye. They walked suffering over the earth and brought longing, sickness for home, here. Others-white women, some of them-turned their faces backward, and then front, and ever after kept their eyes forward. They snapped at their children, grew tough as jack-oak, and brought longing for home here. Men and women in the bellies of slave ships keened longing across the great seas and brought homesickness here.

16 "The land took and held its Indian name, its Choctaw name, okla humma, meaning 'red people,' as the whole of the continent would hold her place names, her mountains and 
rivers, in the tongues that first named them. It lies not in the heart but in the belly, the very gut of the nation, and it contains, like an egg, the whole of the story: red people first and black slaves among them, and soon the tide of white people spreading westward from the eastern hills and mountains across the face of the plains.

"They came overland or by water, by iron rail or wagon or horseback or walking, in a burst of dust and hoof-beats pounding south in the land runs, or sneaking over the borders from the east, hiding in the oak and blackgum hills. Many came to evade the law, some to purge the bile of defeat after the Civil War. Blacks came for freedom here, to build their own towns, their own country. Whites came for land or a new home or to sell whiskey. They came, all of them, bearing their equal measures of pride and violence and hard work and suffering. They came wrapped in decency, steeped in sour greed and hope and despair. In fear and wisdom. In hatred and tolerance. In mindlessness and sorrow and abiding faith in the hand of the Lord. Forsaking all. Forsaking nothing. Bringing it all, every bit of it, with them."

The Mercy Seat has been called an Old Testament-like book-in part because of the title, which derives from the Hebrew Bible, and also, I think, because the language echoes the rhythms and intonations of King James' famous Book. The story deals with a brother killing his brother, like the story of Cain and Abel in the Old Testament. The book can also be read as the story of sinners expelled from the Garden of Eden, continually trying to seek their way home. However, it is also a novel about how the lives of African Americans, Native Americans, and European Americans intersected in Indian Territory in the late 1800's, and it is a book whose spiritual underpinnings include Choctaw Indian religious worldview.

19 Perhaps because I grew up in a place where stories from the Christian Bible came into such direct contact, and conflict, with American Indian spirituality, I'm intrigued by the tension between myth and realism, how that tension, and the juxtaposition of its elements, can be set in relief to reveal certain truths. In some ways, in all my works, I am always writing about the spirit, just as I am always writing about race.

20 Race is the American story, and nowhere has that story played out more dramatically than in Oklahoma. In the years following the American Civil War, which was fought to end slavery in the United States, large numbers of African Americans came to the Territory to escape the continuing violence and oppression in the old slave states. And so if Indian Territory was a place of tragedy for American Indians, and if it represented free land and a fresh start for white Americans, it was, for many black Americans, the New World manifestation of the biblical Promised Land, a place where they believed they could finally live in autonomy, without fear, their last, best hope for freedom. And yet one of the worst race riots in American history took place in Tulsa, Oklahoma, in 1921.

21 We Americans have a hard time dealing with our racial past. We don't like to acknowledge the whole of our history. The race riot that took place in Tulsa was so secret, so covered up for so many generations, that even though I grew up hardly fifty miles away, I never heard a whisper about it in all my young years. None of my grandparents told me this story. We were never taught about it in school. There remains a great shame about this event, when thousands of whites swept into the wealthy black district of North Tulsa and burned it to the ground. Some three hundred people, most of them black, were murdered, and over a thousand homes and businesses were destroyed. It was a terrible paroxysm of racial violence, and yet it was effectively 
forgotten in the nation, and in Oklahoma, for decades. When I finally learned of it in 1989, I knew at once I would write about it, and that I would try to be as accurate with the facts as I possibly could. My efforts to uncover that history took eleven years, but they also coincided, thankfully, with Oklahoma's own willingness to recover the truth. A commission was organized by the state legislature to investigate the riot's history, and the commission's report was issued in 2001, the same year my novel appeared.

That novel, Fire in Beulah, deals not only with issues of racial conflict between blacks and whites and Indians, but also with the great 1920's oil boom in Oklahoma. It tells how the madness of oil fever, like the gold rush fever that came before it, or the Wall Street fever of later years, came near to destroying not only the people caught up in its recklessness, but also the land itself.

In the novel, a mixed-blood woman, Iola Tiger, who is part Muskogee Creek Indian and part black, speaks of the forces of destruction unleashed on the land by the discovery of oil. She is the descendent of the slaves of Indians who came to Oklahoma on the Trail of Tears and also of the Indians themselves. She says:

"One thing I know now, if we going to unleash that power, we going to be the ones receive its sorrow. You look at what happened since the power of that oil get loose. Look at what happened in Tulsa. Look at the whole earth gone to war with itself, not once but twice three times, we all warring each other. How is the world going to make war on itself without oil?"

Fire in Beulah blends the lives of two families, one black and one white, whose juxtaposing stories unfold against a backdrop of oil-boom opulence, fear, hatred, and lynchings, the racial and economic climate of Oklahoma in 1921. In the end, the characters are all caught in the crucible of the riot, and they must make moral choices, but the novel offers them no easy path to redemption.

26 It is this question of redemption-the paying off of a spiritual debt in order to receive forgiveness - that continues to inform my work. It lies at the heart of Fire in Beulahand indeed, I would say that it lies at the heart of America, whether we are conscious of it or not. As a people we want to be redeemed for our country's originals sins of slavery and genocide, but we forget that redemption does not come easily, and it is not free. Part of the American paradox is that, on the one hand, we delight in stories of redemption, tales that reflect "the triumph of the human spirit," that remind us of the old verities William Faulkner spoke about: love and honor and pity and pride and compassion and sacrifice.

On the other hand we also subscribe to a pitiless Western myth of redemption through violence-as if a base act of violence itself can pay the price. Both impulses are simplistic, romantic, sentimental. Sentiment, in its subtlety, can be a grave enemy. It looks at one side only, hides its face from unpleasantness, from responsibility. To surrender to it is to forget that redemption must be earned. It cannot be won without repentance, and repentance, in the old Hebrew understanding of the term, means to turn away from with knowledge. One cannot repent what one will not own. We have to acknowledge the whole of our story, our shames as well as our glories-and often in my country novelists are the ones willing to tell the tale.

Perhaps the most widely known novel about Oklahomans is John Steinbeck's Grapes of Wrath. Steinbeck captures much of what is best in the white American character in his portrait of the Joad family as they leave Oklahoma during the era of the great dust 
storms of the 1930's and head west to California. Steinbeck gets a lot of things right about the shameful way these poor white migrant workers-these Okies-were treated, but in terms of shaping a portrait of Oklahomans, many in Oklahoma have believed that he gets a lot of things wrong. He misunderstands our geography, our religious leanings and social conventions, our language, our notion of sin and salvation.

And so my novel Harpsong undertakes to tell a story from the same era, about the same kinds of people, poor farmers and struggling families-the very same people I come from-but the novel seeks to show a different side. In Harpsong, a gifted harmonicaplaying troubadour, Harlan Singer, and his young wife Sharon travel around the Great Plains, hitchhiking and riding freight trains. Once again this is a story of migration, but not in the classic east-to-west mode; rather the young couple travels in elliptical circles and giant figure eights, but always they return to the homeland, Oklahoma.

Near the end of the book Harlan Singer lies beside a stream of water, mortally wounded and delirious with pain. He remembers the words of an old man named Profit who had once been his mentor. The old man seems to chant in his ear a formula for his dying soul's salvation:

“'No salvation without redemption,' Profit murmurs. 'No redemption without repentance. No repentance without confession of sin.'

'What sin?' the singer asks him.

'No confession without acknowledgment,' the old man answers. 'No acknowledgment without pain.'

In the silence, on the bed of stones, the singer wonders, What sin?

The hills give no answer. He draws his harmonica to his lips, but he cannot play it, he has too little breath. But he can hear the sound of the harp's music echoing through the timber, the clotted canyons, against the far bluffs.

Was it pride? the singer wonders. Was it vanity or greed that caused him to beguile the people, draw them along with his harp's song? No. He had always known the song did not belong to him. He didn't create it. He could only translate it sometimes from the hill's haunted cry.

'Worst is a greedy spirit,' Profit tells him.

'You're wrong,' the singer whispers. 'There's forgiveness for everything."'

If The Mercy Seat is an Old Testament book about sinners in the hands of an angry god, and if Fire in Beulah offers no easy access to absolution, Harpsong is a New Testamentstyled book-the tale of a heartbroken sinner seeking mercy: a mixed-blood American, part white, part black, part Indian, imperfect, filled with longing, seeking a state of grace.

\section{INDEX}

Thèmes : Reconnaissances 